\title{
SEKULARYZACJA RELIGII W TWÓRCZOŚCI RAINERA MARII RILKEGO I GIANNIEGO VATTIMA
}

\begin{abstract}
Streszczenie. Głównym celem artykułu jest analiza fenomenu sekularyzacji w pismach Rainera Marii Rilkego i Gianniego Vattima oraz prezentacja etyki miłosierdzia, zbudowanej na fundamencie religii w wersji słabej, pozbawionej wymiaru nadnaturalnego. Wielu naukowców przyznaje, że w ostatnich latach nastąpiło załamanie paradygmatu sekularyzacji. Okazało się, że nowoczesność i współczesna rewolucja technologiczna nie muszą koniecznie prowadzić do nieuchronnej śmierci religii. Coraz częściej mówi się dzisiaj o desekularyzacji i powrocie religii w zmienionej formie. Najgłębsze znaczenie sekularyzacji dotyczy nie tyle słabnącej obecności religii w domenie publicznej, ile reinterpretacji prawd i symboli religijnych oraz narodzin nowej formy religii o charakterze immanentnym i czysto humanistycznym. Bardzo złożony fenomen sekularyzacji i desekularyzacji wymaga obecnie szeroko zakrojonych badań interdyscyplinarnych.
\end{abstract}

Słowa kluczowe: sekularyzacja, desekularyzacja, społeczeństwo postsekularne, śmierć, nihilizm, hermeneutyka, etyka postmetafizyczna

1. Wprowadzenie. 2. Od sekularyzacji do desekularyzacji. 3. Reiner Maria Rilke i wierność ziemi. 4. Religia w wersji słabej według Gianniego Vattima. 5. Etyczne implikacje sekularyzacji chrześcijaństwa. 6. Podsumowanie.

\section{WPROWADZENIE}

Sekularyzacja oznacza proces stopniowego wyzwalania się poszczególnych dziedzin życia społecznego (polityki, nauki, kultury, edukacji, moralności) oraz życia codziennego ludzi spod wpływów religii i różnego rodzaju instytucji o charakterze kościelnym i wyznaniowym. Amerykański socjolog Peter L. Berger twierdzi, że sekularyzacja ogarnia także „całość życia kulturalnego i twórczego i może być obserwowana na przykładzie zanikania religijnych treści w sztuce, w filozofii, w literaturze oraz - co jest najbardziej znaczące - na 
przykładzie rozwoju nauki jako autonomicznej, zupełnie świeckiej wizji świata. Ponadto (...) proces sekularyzacji ma również stronę subiektywną. Tak jak istnieje sekularyzacja społeczeństwa i kultury, podobnie istnieje sekularyzacja świadomości. Mówiąc prosto, oznacza to, że współczesny Zachód przysporzył nam znaczną liczbę ludzi patrzących na świat i na swoje własne życie z pominięciem interpretacji religijnej”'.

Przez wiele dziesięcioleci dominowała w zachodnim kręgu kulturowym tzw. teoria sekularyzacji, stworzona w oparciu o rozwiązania wypracowane przez Augusta Comte'a, Emila Durkheima i Maxa Webera, zgodnie z którą sekularyzacja jest zjawiskiem powszechnym, prowadzącym nieuchronnie do stopniowego zmierzchu religii, a ostatecznie do jej całkowitego zaniku. Zwolennicy tak rozumianej sekularyzacji twierdzą, że im szybciej nasza cywilizacja podlega różnego rodzaju procesom modernizacyjnym, tym bardziej staje się racjonalna, pragmatyczna i w konsekwencji mniej religijna a nawet ateistyczna czy agnostyczna.

W ostatnim czasie nastąiło załamanie tego rodzaju paradygmatu sekularyzacji. Wielu naukowców mówi wyraźnie o powrocie religii w zmienionej formie. Specyfiką współczesnego podejścia do religii w wielu krajach jest nie tyle jej odrzucenie czy negacja, ile reinterpretacja, która prowadzi do radykalnej zmiany podstawowych treści doktrynalnych. W tym kontekście coraz częściej mówi się o zmianie funkcji religii w społeczeństwie niż o jej zmierzchu. Dotyczy to w sposób szczególny chrześcijaństwa w świecie zachodnim. W konsekwencji tak rozumianej sekularyzacji dochodzi do reinterpretacji symboli i prawd religii chrześcijańskiej, które tracą swój rzeczywisty i obiektywny charakter, stając się jedynie elementami życia zbiorowego ludzi i estetycznymi symbolami kultury. Prekursorem takiego podejścia do religii na początku XX wieku był austriacki poeta Rainer

1 P.L. Berger, Sekularyzacja a problem wiarygodności religii, tłum. z ang. W. Kurdziel, w: Ateizm oraz irreligia i sekularyzacja, red. F. Adamski, Kraków 2011, 98. 
Maria Rilke. Natomiast obecnie postrzega w ten sposób religię m.in. włoski filozof Gianni Vattimo.

Jak należy rozumieć proces powrotu religii i stopniowej desekularyzacji? W czym tkwi istota epoki postsekularnej? Na czym polega transformacja prawd i symboli religijnych w twórczości Rilkego? Jak można określić istotę religii w wersji słabej w interpretacji Vattima? Czy można zbudować etykę na fundamencie miłosierdzia chrześcijańskiego, które zostało poddane głębokiemu procesowi sekularyzacji?

Głównym celem artykułu jest analiza fenomenu sekularyzacji religii w pismach Rainera Marii Rilkego i Gianniego Vattima oraz prezentacja najważniejszych idei etyki miłosierdzia, zbudowanej na fundamencie religii, która została poddana procesowi sekularyzacji.

\section{OD SEKULARYZACJI DO DESEKULARYZACJI}

Jednym z niezwykle wymownych symboli sekularyzacji jest metafora "odczarowania świata" (die Entzauberung der Welt), którą wprowadził do domeny publicznej niemiecki filozof i socjolog Max Weber na początku XX wieku². Jego zdaniem, rozwój nauki i techniki oraz racjonalizacja rzeczywistości w epoce nowożytnej doprowadziły do stopniowego zaniku znaczenia symboli, sił i mocy religijnych, które $\mathrm{w}$ poprzednich epokach historycznych miały charakter tajemniczy, nieznany, nadprzyrodzony. To one decydowały w przeszłości o losach świata i człowieka. Przez tysiąclecia ludzkość potrzebowała magii, duchów i religii, żeby wytłumaczyć świat i sprawować nad nim władzę. Weber twierdzi, że trwający przez tysiąclecia „proces odczarowania" (der Entzauberungsprozeß) bardzo przyspieszył wraz

2 Wyrażenie „odczarowanie świata” zostało użyte po raz pierwszy przez Maxa Webera w Monachium w 1917 r. podczas jednego z wykładów nt. Nauka jako zawód. Ta ważna konferencja niemieckiego filozofa i socjologa została opublikowana dwa lata później. Por. M. Weber, Wissenschaft als Beruf, w: tenże, Schriften 1894-1922. Ausgewählt und herausgegeben von Dirk Kaesler, Stuttgart 2002, 474-511. 
z nowożytną rewolucją naukowo-techniczną, która pozwala człowiekowi sprawować władzę nad światem bez korzystania z pomocy sił o charakterze nadprzyrodzonym. W konsekwencji dominująca w poprzednich epokach historycznych magiczna czy religijna interpretacja rzeczywistości przestała być potrzebna ${ }^{3}$.

Koncepcję sekularyzacji wypracowaną przez Webera rozwinęło m.in. dwóch myślicieli niemieckich: filozof i socjolog Ernst Troeltsch oraz filozof i teolog Friedrich Gogarten. Pierwszy z nich zwrócił uwage na zasadniczy wkład protestantyzmu w procesie „odczarowania świata” i pokazał ciągłość między kulturą zsekularyzowaną a wiarą chrześcijańską. Natomiast drugi - nazywany ojcem teologii sekularyzacji - ukazał ją jako wydarzenie, które stanowi prostą konsekwencję istoty wiary chrześcijańskiej. Gogarten twierdzi, że religia chrześcijańska jest podstawą sekularyzacji - pozwala zdobyć człowiekowi wolność od mitycznych i magicznych sił przyrody, przekazuje w ręce ludzi sprawowanie władzy nad światem. Relacja „między wiarą i sekularyzacją jest taka, że nie ma wiary bez sekularyzacji relacji człowieka wierzącego ze światem"4. W ten sposób kategoria sekularyzacji zyskała funkcję zrozumienia autonomii świata nowożytnego, ukształtowanego na gruncie cywilizacji chrześcijańskiej, który stał się światem zsekularyzowanym.

3 „Die zunehmende Intellektualisierung und Rationalisierung bedeutet also nicht eine zunehmende allgemeine Kenntnis der Lebensbedingungen, unter denen man steht. Sondern sie bedeutet etwas anderes: das Wissen davon oder den Glauben daran: daß man, wenn man nur wollte, es jederzeit erfahren könnte, daß es also prinzipiell keine geheimnisvollen unberechenbaren Mächte gebe, die da hineinspielen, daß man vielmehr alle Dinge - im Prinzip - durch Berechnen beherrschen könne. Das aber bedeutet: die Entzauberung der Welt. Nicht mehr, wie der Wilde, für den es solche Mächte gab, muss man zu magischen Mitteln greifen, um die Geister zu beherrschen oder zu erbitten. Sondern technische Mittel und Berechnung leisten das. Dies vor allem bedeutet die Intellektualisierung als solche“. Tamże, 488.

4 F. Gogarten, Destino e speranza dell'epoca moderna. La secolarizzazione come problema teologico, Brescia 1972, 145. 
Do poglądów Webera, Troeltscha i Gogartena nawiązywało w XX wieku wielu autorów, którzy tworzyli własne koncepcje sekularyzacji jako procesu nieuchronnej marginalizacji religii i jej stopniowego zaniku. Sytuacja zaczęła się zmieniać pod koniec ubiegłego wieku, gdy pojawiły się pierwsze próby zakwestionowania paradygmatu sekularyzacji jako procesu, który prowadzi nieuchronnie do całkowitej śmierci religii. „Od połowy lat dziewięćdziesiątych - pisze Janusz Mariański - niektórzy socjologowie mówią o procesach desekularyzacji i deprywatyzacji, a nawet resakralizacji we współczesnym świecie, także częściowo i w Europie Zachodniej. Religia zmienia swoje formy i swoje miejsce w społeczeństwie" .

W ostatniej dekadzie ubiegłego wieku miała miejsce w wielu krajach tzw. debata na temat sekularyzacji (Secularization Debate), która wyraźnie pokazała, że obecnie potrzeba $\mathrm{w}$ świecie nie tyle teorii dotyczącej zmierzchu religii, ile podjęcia nowych badań nad różnymi przejawami ożywienia religijnego i współczesną metamorfozą postrzegania religii w różnych modelach cywilizacyjnych ${ }^{6}$. W połowie lat 90. ubiegłego wieku o zmierzchu paradygmatu sekularyzacji pisał m.in. włoski filozof i socjolog Massimo Introvigne, który wykazywał w swoich opracowaniach nieadekwatność tej koncepcji w wymiarze kulturowym oraz pokazywał przejawy nowego zainteresowania problematyką religijną. Jego zdaniem, pod koniec XX

5 J. Mariański, Sekularyzacja i desekularyzacja w nowoczesnym świecie, Lublin 2006, 19.

6 „The »secularization debate «(...) pits advocates of a new, rational-choice »paradigm « - the so-called religious economies model - against defenders of classical and neoclassical secularization theory. Supporters of the new paradigm propose »dropping the term secularization from all theoretical discourse... What is needed «, they argue, »is not a theory of the decline or decay of religion, but of religious change «". Ph. S. Gorski, Historicizing the Secularization Debate: Church, State, and Society in Late Medieval and Early Modern Europe, CA. 1300 to 1700, w: Secularization, t. I, Defining Secularization. The Secular in Historical and Comparative Perspective, red. B. S. Turner, Los Angeles 2010, 117. 
stulecia sekularyzacja przestała być traktowana jako proces linearny i nieodwracalny, który prowadzi do zaniku religijności ${ }^{7}$.

W 1999 r. włoski filozof Salvatore Natoli wprowadził do domeny publicznej pojęcie „drugiej sekularyzacji” (seconda secolarizzazione). Jego zdaniem, w obecnej epoce historycznej mamy do czynienia z pewnym rodzajem drugiej sekularyzacji, która oznacza sekularyzację sekularyzacji. „Jeśli pierwsza - dodaje Natoli - była sekularyzacją zbawienia, ta współczesna stanowi sekularyzację od zbawienia"8. Oznacza to, że przechodzimy od zbawienia poza czasem w wymiarze transcendentnym, do zbawienia w czasie o charakterze immanentnym i czysto humanistycznym, niszcząc w ten sposób samą religijną ideę zbawienia.

Na przestrzeni ostatnich 20 lat pojawiło się wiele krytycznych ocen różnego rodzaju teorii sekularyzacji. Na początku obecnego stulecia wielu naukowców - na czele z Peterem L. Bergerem - przyznało się do błędnych prognoz i zweryfikowało wcześniejsze przewidywania dotyczące zaniku religijności w świecie zachodnim. Wielu autorów mówi obecnie o narodzinach nowego społeczeństwa postsekularnego. Okazało się, że model zachodnioeuropejskiej sekularyzacji nie jest wzorem dla wszystkich społeczeństw, a sekularyzacja nie stanowi nieuchronnej konsekwencji procesów modernizacyjnych, gdziekolwiek się one pojawią.

Pojęcie „desekularyzacji świata” (Desecularization of the World) stworzył pod koniec ubiegłego wieku Peter L. Berger9 ${ }^{9}$ Procesy desekularyzacyjne można ujmować na dwóch płaszczyznach: jako przejście od religijności kościelnej do pozakościelnej oraz jako proces indywidualizacji religijnej. Pierwsze zjawisko łączy się z fragmentary-

7 Por. M. Introvigne, Il sacro postmoderno. Chiesa, relativismo e nuovi movimenti religiosi, Milano 1996.

8 S. Natoli, Dio e il divino. Confronto con il cristianesimo, Brescia 1999, 119.

9 Por. P. L. Berger, The Desecularization of the World. A Global Overview, w: The Desecularization of the World. Resurgent Religion and World Politics, red. tenże, Washington D.C. $1999,1-18$. 
zacją religii i wspólnot wyznaniowych, natomiast indywidualizacja religii oznacza autonomiczne konstruowanie przez jednostki własnych preferencji i reguł o charakterze religijnym. Desekularyzacja staje się powoli faktem globalnym, podobnie jak stała się nim uprzednio sekularyzacja. $\mathrm{Na}$ międzynarodowej scenie religijnej obserwuje się wzrost znaczenia ruchów konserwatywnych, ortodoksyjnych i tradycjonalistycznych, odrzucających kompromisy z nowoczesnością czy przystosowanie się do niej. Janusz Mariański twierdzi, że „wszystkie te przejawy desekularyzacyjne wskazują, że nie można w sposób bezwzględny łączyć modernizacji i sekularyzacji. Kontrsekularyzacja jest przynajmniej równie ważnym zjawiskiem we współczesnym świecie jak sekularyzacja. Współgranie sił sekularyzacji i kontrsekularyzacji jest jednym z ważnych tematów współczesnej socjologii religii”"10.

O zmierzchu paradygmatu sekularyzacji mówi także bardzo wyraźnie niemiecki filozof Jürgen Habermas, który w ubiegłym stuleciu prezentował negatywne podejście do religii. Niemiecki myśliciel, związany z tradycją filozoficzną Szkoły Frankfurckiej, określa się mianem człowieka „pozbawionego religijnego słuchu”. Przez wiele dziesięcioleci uważał, że powszechna solidarność między ludźmi możliwa jest dzięki rozumowi komunikacyjnemu działającemu w moralnych dyskursach. Do końca ubiegłego wieku Habermas głosił tezę, że w dzisiejszym świecie religia jest skazana na całkowite wymarcie, a jej funkcje społeczne powinna przejąć moralność ugruntowana i zracjonalizowana przez dialog ${ }^{11}$.

Nowa ocena fenomenu religii została zaprezentowana przez niemieckiego filozofa jesienią 2001 r. w szeroko komentowanym wykładzie pt. Wierzyć $i$ wiedzieć. Habermas wygłosił to ważne przemówienie podczas uroczystości z okazji otrzymania Nagrody

10 J. Mariański, Sekularyzacja i desekularyzacja w nowoczesnym świecie, dz. cyt., 77. Por. tenże, Sekularyzacja, desekularyzacja. Nowa duchowość. Studium socjologiczne, Kraków 2013.

11 Por. Z. Krasnodębski, Społeczeństwo postsekularne, Znak 562(2002)3, 8. 
Pokojowej Księgarzy Niemieckich, która jest przyznawana corocznie od 1950 r. i wręczana w trakcie Międzynarodowych Targów Książki we Frankfurcie nad Menem. Wykład niemieckiego filozofa zaskoczył wielu słuchaczy, ponieważ zostało w nim przedstawione radykalnie zmienione podejście do religii. Habermas stwierdził, że nie wolno dążyć do marginalizacji religii i wykluczania wszelkich przejawów życia religijnego ze sfery publicznej. Jego zdaniem, współczesne społeczeństwa demokracji liberalnej nie są zupełnie świeckie, lecz są społeczeństwami postsekularnymi, czyli takimi, „gdzie w otoczeniu wciąż podlegającym sekularyzacji nadal istnieją wspólnoty religijne"12. W społeczeństwach postsekularnych drga „religijna struna”.

W kwietniu 2016 r. na łamach prestiżowego włoskiego dwutygodnika „La Civiltà Cattolica” ukazał się artykuł Giandomenico Mucciego pt. Potrzeba Boga, który stanowi kontynuację analiz fenomenu sekularyzacji i desekularyzacji w wydaniu Habermasa, Bergera czy Natoliego ${ }^{14}$. Mucci stwierdza, że potrzeba Boga - na poziomie indywidualnym i społecznym - jest faktem zakorzenionym także w obecnej fazie rozwoju nowożytności. Świadczy o tym niezaprzeczalne przebudzenie religijne, które zadziwiło i rozczarowało teoretyków sekularyzacji. Mamy dzisiaj rzeczywiście do czynienia ze zmierzchem paradygmatu, zgodnie z którym nowoczesność jest sprzeczna $z$ religią. Mucci potwierdza opinię wielu innych badaczy, że na naszych oczach wyczerpała się globalna teoria sekularyzacji. Okazało się, że procesy modernizacyjne społeczeństw nie muszą iść koniecznie w parze z wyparowaniem religijności. Śmierć teorii globalnej sekularyzacji nie oznacza jednak zaniku procesów sekularyzacyjnych. Sekularyzacja religii jest dzisiaj często zastępowana

12 J. Habermas, Wierzyć i wiedzieć, Znak 568(2002)9, 11.

13 Por. C. Jahnel, „Entwicklung“: ein säkulares Heilsversprechen? Religion und Entwicklung post-säkular denken und interpretieren, Berliner Theologische Zeitschrift 32(2015)2, 319-342.

14 Por. G. Mucci, Il bisogno di Dio, La Civiltà Cattolica 3980(2016)8, 182-186. 
pluralizmem religijnym i skrajnie indywidualnym podejściem do różnych form religijności.

$Z$ jednej strony, procesy sekularyzacyjne sprawiają, że religia staje się coraz bardziej sprawą wyborów indywidualnych. Sekularyzacja jest interpretowana dzisiaj nie tyle jako uwalnianie się różnych dziedzin życia od wpływu religii, ile jako fakt prywatyzacji religii; religia nie znika, ale zmienia swoje znaczenie, staje się kwestią wyborów o charakterze indywidualnym. Tak rozumiana sekularyzacja oznacza przesunięcie religijności $\mathrm{z}$ wymiaru instytucjonalnego do sfery emotywno-osobistej. Jednym $z$ ważnych aspektów prywatyzacji religii jest osłabienie jej charakteru instytucjonalnego. $Z$ drugiej jednak strony, procesy desekularyzacyjne przywracają religii ważne miejsce w życiu publicznym i prowadzą do ponownego odkrycia wielu różnych funkcji społecznych religii. Tego rodzaju zjawiska występują nie tylko w społeczeństwach postsekularnych, o których pisze Habermas, ale są naturalnym elementem funkcjonowania społeczeństw odwołujących się do tradycji religijnej islamu, buddyzmu czy hinduizmu.

Wydaje się, że w obecnym sporze o sekularyzację i desekularyzację sprawą najważniejszą jest nie tyle miejsce religii w życiu publicznym, ile dokonująca się na naszych oczach głęboka reinterpretacja prawd i symboli o charakterze religijnym. W tym względzie za niezwykle cenne należy uznać analizy Rainera Marii Rilkego i Gianniego Vattima, które odsłaniają nam najgłębsze pokłady współczesnej metamorfozy fenomenu religii w wymiarze globalnym.

\section{RAINER MARIA RILKE I WIERNOŚĆ ZIEMI}

Bogata i inspirująca twórczość Rilkego, autora Sonetów do Orfeu$s z a$ i wielu innych wybitnych dzieł literackich, stała się w ubiegłym stuleciu przedmiotem pogłębionych analiz wielkich filozofów m.in. Martina Heideggera i Hansa-Georga Gadamera. Gdy chodzi o problem sekularyzacji w utworach tego poety, szczególnie cenne są 
badania niemieckiego myśliciela Romano Guardiniego, który zwrócił uwagę na dokonaną przez Rilkego głęboką reinterpretację podstawowych pojęć religii chrześcijańskiej ${ }^{15}$. Guardini uznał austriackiego poetę za proroka czystej skończoności, który wyraża swoją religijną wierność ziemi jako decydującemu i ostatecznemu horyzontowi naszej egzystencji. Autor Sonetórw do Orfeusza jest interpretowany przez Guardiniego nie jako zwykły poeta, ale jako wieszcz nowej epoki sekularyzacji naznaczonej przez religijność postchrześcijańską.

Specyfiką sekularyzacji w twórczości Rilkego nie jest odrzucenie religijnej wizji świata i człowieka, ale zredukowanie fenomenu religii do czystej immanencji antropologiczno-kosmologicznej. W konsekwencji religia w wersji zsekularyzowanej traci jakikolwiek charakter transcendentny, natomiast ludzka egzystencja zostaje ograniczona do wymiaru czysto doczesnego. Twórczość tego poety wyraża zamknięcie rzeczywistości sacrum i numinosum $\mathrm{w}$ obrębie całkowitej immanencji. $Z$ jednej strony, Rilke interpretuje chrześcijaństwo jako przestarzałą i negatywną formę życia religijnego, z drugiej - w swoim języku poetyckim ciągle odwołuje się do pojęć i postaci chrześcijańskich, odrywając je od ich autentycznych korzeni i prowadząc w ten sposób do ich sekularyzacji.

Rilke pozostawał pod dużym wpływem filozofii i literatury rosyjskiej. Szczególną rolę w ukształtowaniu jego własnej wizji świata i człowieka odegrały dzieła Lwa Tołstoja ${ }^{16}$. W twórczości austriackiego poety - podobnie jak w poezji Fryderyka Hölderlina czy Fryderyka Schillera - są obecne motywy magiczne, mitologiczne, alchemiczne, ezoteryczne ${ }^{17}$. Dlatego można mówić o powrocie w dziełach tych autorów różnego rodzaju elementów i postaci kultury

15 Por. R. Guardini, Rainer Maria Rilke. „Le Elegie duinesi” come interpretazione dell'esistenza, Brescia 1974.

16 Por. K. Wawrzynek, Rainer Maria Rilke and his Mystical Russia, Studia Europaea Gnesnensia 7(2013), 263-284.

17 Por. F. Jesi, Esoterismo e linguaggio mitologico. Studi su Rainer Maria Rilke, Macerata 2002. 
pogańskiej, politeistycznej - Prometeusza, Ulissesa, Orfeusza, Apolla czy Dionizjusza ${ }^{18}$. Warto podkreślić, że wymieszanie elementów pogańskich z pewnymi ideami myśli chrześcijańskiej - obecne w twórczości Rilkego, Hölderlina czy Schillera - jest także jedną z cech charakterystycznych współczesnej kultury postmodernistycznej.

Niektórzy badacze nazywają austriackiego poetę „kosmopolitycznym pielgrzymem", który dokonuje sekularyzacji pojęć religijnych ${ }^{19}$. Rilke poddaje głębokiej reinterpretacji przede wszystkim podstawowe kategorie religii chrześcijańskiej. W jego twórczości pojawiają się bardzo często takie wyrażenia, jak Bóg, Chrystus, Maryja czy zbawienie, które są zwykłymi znakami słownymi bez realnych odniesień. W czym zatem tkwi istota wymiaru religijnego w wersji zsekularyzowanej? Zdaniem Rilkego, postawa religijna pozbawiona wymiaru transcendentnego, wyraża wewnętrzne dążenie człowieka do czegoś, co jest całkowicie inne, oraz poszukiwanie doskonałości i pełni bytu ludzkiego ${ }^{20}$. Autor Sonetów do Orfeusza prezentuje religijność zsekularyzowaną, która nie jest otwarta na Objawienie chrześcijańskie, ale zostaje wchłonięta całkowicie przez rzeczywistość świata.

Jednym z przykładów sekularyzacji prawd chrześcijańskich w twórczości Rilkego jest jego reinterpretacja i estetyzacja biblijnego obrazu anioła. Guardini twierdzi, że autor Sonetów do Orfeusza kontynuuje dzieło sekularyzacji figury anioła rozpoczęte już przez Hölderlina, u którego aniołowie są zwykłymi siłami mitycznymi - bez

18 Por. A. Stock, Linien des Lebens. Zu späten Gedichten Hölderlins, Stimmen der Zeit 141(2016)2, 115-120; M. Augé, Genio del paganesimo, Torino 2002, 295-301.

19 Por. N. Fischer, Rilkes Zugang zur Religion. Gegen die Hypothese seiner „Immanenz-Gläubigkeit“, w: „Gott“ in der Dichtung Rainer Maria Rilkes, red. tenże, Hamburg 2014, 69-106; G. Wacker, Poetik des Prophetischen. Zum visionären Kunstverständnis in der Klassischen Moderne, Berlin - Boston 2013, 178-255; M. King, Säkularisierung und Re-Sakralisierung: Rainer Maria Rilke als „poeta vates“der Moderne, w: Ästhetik - Religion Säkularisierung, t. II, Die klassische Moderne, red. S. Vietta, S. Porombka, München 2009, 89-107.

20 Por. A. Destro, Rilke. Il Dio oscuro di un giovane poeta, Padova 2003. 
zakorzenienia w Objawieniu biblijnym ${ }^{21}$. Aniołowie Rilkego eliminują Boga Objawienia, który jest rzekomo zagrożeniem dla wolności i autonomii człowieka. W ten sposób aniołowie zajmują miejsce Bytu Najwyższego - nie są biblijnymi pośrednikami między Bogiem i ludźmi, ale stają się najwyższą samodzielną formą boskości. Co więcej, aniołowie autora Sonetów do Orfeusza są obojętni na los człowieka. Anioł Rilkego „nie chce burzyć, dlatego trzyma się daleko od człowieka. To jednakże nie znaczy, że bierze sobie do serca sprawy człowieka lub że go kocha. Człowiek go po prostu nie interesuje. Anioł przebywa w wysokościach nieosiągalnych przez człowieka. Nie istnieje, jak człowiek, w sferze ziemskiej, ani także - jak zmarliw sferze pozaziemskiej, lecz trwa w relacji z całością istnienia, która składa się z wymiaru ziemskiego i pozaziemskiego"22.

Twórczość austriackiego poety nawiązuje m.in. do Fryderyka Nietzschego, gdy akcentuje śmierć bogów i wskazuje na niebo, które jest puste. W konsekwencji człowiek powinien stać się nowym bytem w oparciu o twórczość artystyczną. Co więcej, w ujęciu Rilkego sztuka stanowi źródło nieśmiertelności estetycznej. Taką wizję zawiera m.in. wiersz Listy do mtodego poety. $Z$ twórczością artystyczną łączy się pamięć, która jest formą życia wiecznego ${ }^{23}$. W przypadku Rilkego można mówić o swego rodzaju autosakralizacji (Selbstsakralisierung), która jest bardzo widoczna szczególnie w jego niezwykle bogatej wymianie listów $\mathrm{z}$ wieloma ważnymi i ciekawymi postaciami swojej epoki ${ }^{24}$.

Poezja austriackiego autora może być nazwana religio mortis - opisuje tajemniczą relację istniejącą między życiem ludzkim a śmiercią, definiując śmierć jako wewnętrzną przestrzeń ludzkiej egzystencji.

21 Por. R. Guardini, Studi su Dante, Brescia 1986, 38.

22 Tenże, Rainer Maria Rilke, dz. cyt., 32.

23 Por. E. Manera, La poetica di R. M. Rilke nella riflessione sul mito di Furio Jesi, Estetica (2009)1, 21-47.

24 Por. M. King, Pilger und Prophet: heilige Autorschaft bei Rainer Maria Rilke, Göttingen 2009. 
W wielu utworach Rilke pisał o dojrzewaniu własnej śmierci. Temat śmierci i umierania jest bardzo wyraźnie obecny w Elegiach duinejskich oraz w Sonetach do Orfeusza. Postaci anioła, dzieci, porzuconych kochanek, przepełnionych uczuciem miłości kochanków czy osób zmarłych w młodym wieku pozostają w naturalnej relacji do śmierci. To właśnie śmierć łączy wszystkich, tworzy swego rodzaju wspólnotę żywych i umarłych, stając się wielką metonimią fenomenologii skończoności ${ }^{25}$.

Hans-Georg Gadamer twierdził, że w Elegiach duinejskich nastąił u Rilkego „Zwrot mitopoetycki” (mythopoietische Umkehrung) ${ }^{26}$. Jego istotą jest ukazanie wiary w nieśmiertelność, która wyrasta $\mathrm{z}$ kontaktu ze śmiercią. Tylko ten, kto poznał obecność i mądrość zmarłych, może zdobyć nieśmiertelność. Przewodniczkami poety po królestwie zmarłych są lamentacje (die Klagen): tajemnicze personifikacje rytuałów pogrzebowych, które nie mają jakichkolwiek odpowiedników $\mathrm{w}$ historii religii, ale tworzą syntezę a posteriori wszystkich rytuałów pogrzebowych ludzkości $\mathrm{w}$ archetypie doświadczenia śmierci. Obecność śmierci nie jest celem samym w sobie - stanowi raczej część zstępującą cyklu, który przewiduje powrót: ze śmiercią łączą się nierozerwalnie idee narodzin, przyszłości i nadziei, znajdujące swój szczególny obraz w kategorii dzieciństwa.

Zmarli, aby dobrze odnaleźć się w nowym świecie, muszą odzyskać to wszystko, czego nie udało im się dokonać w ciągu życia. Śmierć nie stanowi nieszczęścia, ponieważ forma życia ludzi zmarłych nie jest mniej realna niż egzystencja ludzi żywych. Świat zmarłych należy do tej samej rzeczywistości, co ziemski świat i razem z nim tworzy jedną wielką całość egzystencji. W poezji Rilkego umieranie jawi się jako proces, który dokonuje się wewnątrz całości świata. Bycie umarłym „oznacza tutaj przeciwną formę życia, bardziej dokładnie,

25 Por. E. Laudazi, Dio e l'uomo nelle „Elegie duinesi” di R. M. Rilke, Rivista di Vita Spirituale 62(2008)1, 53-68.

26 Por. H.-G. Gadamer, Kleine Schriften II, Tübingen 1967, 194-209. 
jego najbardziej właściwą autentyczność” ${ }^{27}$. W tej gnostyckiej wizji świata i człowieka śmierć nie jest negacją życia, jak zło nie jest negacją dobra, ale jedynie przeciwstawnym biegunem dobra. W ten sposób wszystkie elementy, także życie i śmierć, zostają wchłonięte przez wielką jedność egzystencji.

W poezji Rilkego szczególną rolę odgrywa kontakt ludzi żyjących ze światem zmarłych. Świadomość śmierci sprawia, że rodzi się w nas potrzeba trwania absolutu pamięci i wyobraźni. Przeżywanie fenomenu śmierci oraz podtrzymywanie żywej relacji ze światem zmarłych pomagają ludziom żyjącym pokonać własną skończoność i uzdalniają ich do głębszego doświadczenia własnej egzystencji. W interpretacji fenomenu śmierci i umierania Rilke nawiązuje do wielkiej tradycji literackiej Homera, Wergiliusza czy Dantego, w której spotkanie ze zmarłymi buduje przyszłość na gruncie przeszłości, tworzy ciągłość pamięci i umacnia tradycję.

W utworach austriackiego poety świat zmarłych stanowi realną część naszej aktualnej rzeczywistości ${ }^{28}$. Zmarli są obecni pośród nas, można słyszeć ich głosy, można wchodzić $\mathrm{z}$ nimi w różnego rodzaju relacje. Żywych i zmarłych łączy szczególna więź. Rilke traktuje zmarłych i ich królestwo jako realne i zasadnicze dla świata: co więcej, przyznaje im szczególne znaczenie w kontekście losów ludzi żyjących i całego wszechświata. Widać tutaj wyraźnie powrót do religijności mitycznej i pewne związki z formami okultystycznymi. W Elegiach duinejskich Rilke pisze: „A śmierć nasza mozołem jest i ciągłym doganianiem, aby z wolna wczuwać się w wieczność. Lecz wszyscy żywi popełniają ten sam błąd, zbyt mocno odróżniając. Powiadają, że aniołowie nie wiedzą często, czy idą wśród żywych, czy umarłych. Prąd odwieczny wciąż porywa z sobą wszystkie pokolenia z jednego obszaru w drugi i tłumi ich odgłosy w obydwu. Wreszcie

27 R. Guardini, Rainer Maria Rilke, dz. cyt., 479.

28 Por. A. Kobyliński, Sekularyzacja i doświadczenie religijne, Collectanea Theologica 76(2006)1, 142-144. 
owi przedwcześnie zmarli nie żądają nas więcej i lekko odwykają od ziemi, tak jak łagodnie odwyka się od piersi matki. Lecz my, którym potrzebne są wielkie tajemnice, którym żałoba bywa natchnieniem duszy, czy bez nich moglibyśmy istnieć?”29.

Ze śmiercią łączy się tutaj idea nieśmiertelności w wersji immanentnej i zsekularyzowanej. Autor Sonetów do Orfeusza świadomie odrywa nieśmiertelność od wieczności i transcendencji, aby połączyć ją ze śmiercią i umieraniem. Podstawą takiego stanowiska jest przekonanie, że zmarli są obecni w duszach ludzi żyjących. Nieśmiertelność trwa tak długo, jak długo żyje ktoś, kto pamięta. Śmiertelność jest czynnikiem, który wytwarza nieśmiertelność jako warunek szczęścia i wiecznej radości, ponieważ określa konieczność trwania podmiotu w czasie - jak dzieło sztuki, które żyje także po śmierci artysty.

\section{RELIGIA W WERSJI SŁABEJ WEDŁUG GIANNIEGO VATTIMA}

Reinterpretacja symboli i prawd religii chrześcijańskiej, rozpoczęta przez Rilkego, jest dzisiaj kontynuowana m.in. przez Vattima, który proponuje nową wizję chrześcijaństwa - bez dogmatów, w wersji zsekularyzowanej i nihilistycznej, zrywającą ciągłość z tradycją. W twórczości tego autora istnieje ścisła więź między sekularyzacją, nihilizmem i hermeneutyką ${ }^{30}$. Sekularyzacja stanowi formę pojednania między nihilizmem i chrześcijaństwem. Co więcej, Vattimo postuluje utożsamienie nihilizmu i sekularyzacji ${ }^{31}$. Skąd wyrasta koncepcja religii włoskiego filozofa? Jakie są jej korzenie? Co jest fundamentem takiej wizji sekularyzacji i chrześcijaństwa?

Kluczem do zrozumienia filozofii Vattima jest kategoria myśli słabej (pensiero debole), która rodzi się na zgliszczach myśli mocnej,

29 R.M. Rilke, Elegie duinejskie, w: tenże, Kto mówi o zwycięstwach? Przetrwanie jest wszystkim!, tłum. z niem. B. Antochewicz, Wrocław 1994, 153.

30 Por. M. Harris, Vattimo, Nihilism and Secularization: the "Trojan Horse" Effect of Christianity, Parrhesia 9(2014), 51-64.

31 Por. G. Vattimo, Addio alla verità, Roma 2009, 73. 
symbolizującej zanik tradycyjnej racjonalności o charakterze obiektywnym i uniwersalnym, jaka charakteryzowała minione stulecia. Myśl słaba wyraża współczesny zmierzch wiary w rzeczywistość, rozumianą jako zbiór obiektywnych norm, praw, regul, idei. Sekularyzacja wyrastająca na fundamencie myśli słabej - utożsamiona z nihilizmem jako zespołem pojęć, prawd, myśli i zachowań, zdominowanych przez pojęcie nicości - nie jest odrzuceniem tego, co religijne, ale stanowi swego rodzaju pozytywne przewartościowanie tradycyjnego stosunku do religii. W konsekwencji sekularyzacji, rozpad tradycyjnych struktur społeczeństw chrześcijańskich prowadzi do narodzin moralności autonomicznej i mniej rygorystycznej interpretacji prawd religijnych ${ }^{32}$. Podobnie jak w twórczości Rilkego, sekularyzacja nie oznacza tutaj zaniku chrześcijaństwa czy pożegnania $z$ nim, ale pełniejszą realizację jego prawdy, którą jest kenoza - uniżenie się Boga oraz zakwestionowanie „naturalnych” i transcendentnych cech Bytu Najwyższego ${ }^{33}$.

Vattimo wyznaje w wielu swoich pismach, że jego pozytywne rozumienie sekularyzacji zostało zaczerpnięte zasadniczo $\mathrm{z}$ opracowań francuskiego filozofa René Girarda, pojmującego chrześcijaństwo jako zasadę destrukturyzacji wszystkich kultów archaicznych ${ }^{34}$. Girard twierdził, że chrześcijaństwo jak koń trojański zamieszkało pośród religii naturalnych po to, żeby je od środka poddać procesowi transformacji, demityzacji i desakralizacji. W tym sensie chrześcijaństwo odpowiada za sekularyzację świata i pewną formę zmierzchu

32 Por. tenże, Credere di credere. È possibile essere cristiani nonostante la Chiesa?, Milano 1996, 19992, 40-42.

33 „Il cristianesimo ritrovato come dottrina della salvezza, e cioè della kenosis e della secolarizzazione, non è dunque un patrimonio di dottrine definite una volta per tutte, a cui rivolgersi per trovare finalmente un terreno solido nel mare di incertezza e nella Babele di linguaggi del mondo postmetafisico; fornisce però un principio critico sufficientemente netto per orientarsi sia nei confronti di questo mondo sia, anzitutto, nei confronti della Chiesa, sia infine nei confronti dello stesso processo di secolarizzazione". Tamże, 60.

34 Por. G. Vattimo, R. Girard, Verità o fede debole? Dialogo su cristianesimo e relativismo, Massa 2006, 7-9. 
religii. Ateizm w jego znaczeniu nowożytnym jest zatem owocem sekularyzacji dokonanej przez chrześcijaństwo.

„Jeśli sekularyzacja - podkreśla Vattimo - jest sposobem, w jaki dokonuje się osłabienie bycia, tzn. kénosis Boga - co stanowi istotę historii zbawienia - to nie może być rozumiana jako fenomen porzucenia religii, ale jako wypełnienie jej wewnętrznej misji. Filozofia właściwie postmetafizyczna powinna usiłować zrozumieć potrzebę szacunku dla tego powołania do osłabienia i sekularyzacji oraz krytykować różne fenomeny powrotu religii w naszej kulturze" ${ }^{35}$.

Włoski myśliciel twierdzi, że prawdy religijne poddane reinterpretacji w ramach procesu sekularyzacji mają znaczenie jedynie metaforyczne. Tego rodzaju religijność, zsekularyzowana i pozbawiona transcendencji, nie akceptuje jakichkolwiek dogmatów religijnych czy moralności o charakterze obiektywnym i normatywnym. Gdy chodzi o chrześcijaństwo, Vattimo postuluje, aby reinterpretacji poddać wszystkie dogmaty i prawdy moralne należące do dziedzictwa biblijnego, z wyjątkiem przekonania, że Bóg jest miłością. W ten sposób zostaje zakwestionowany Byt Najwyższy rozumiany jako obiektywność, racjonalność czy ostateczny fundament rzeczywistości.

W filozofii Vattima Bóg staje się jedynie wydarzeniem - nie jest kimś lub czymś, co znajduje się gdzieś realnie w innym wymiarze transcendentnym poza porządkiem świata widzialnego. Negacja transcendencji prowadzi do demityzacji moralności i dogmatów chrześcijańskich, aby uczynić religię bardziej dostępną i akceptowalną dla człowieka współczesnego. Sekularyzacja w wydaniu Vattima podobnie jak zasada wierności ziemi Rilkego - rodzi de facto nową wizję chrześcijaństwa świeckiego, humanistycznego i pozbawionego transcendencji. $Z$ jednej strony, zostają zachowane wcześniejsze pojęcia religijne i symbole chrześcijańskie, $z$ drugiej - tracą one swoje realne desygnaty, stają się jedynie formą języka metaforycznego.

35 G. Vattimo, Dopo la cristianità. Per un cristianesimo non religioso, Milano 2002, 28. 


\section{ETYCZNE IMPLIKACJE SEKULARYZACJI CHRZEŚCIJAŃSTWA}

Sekularyzacja jako reinterpretacja orędzia chrześcijańskiego prowadzi do powstania nowego modelu etycznego, nazywanego przez Vattima etyką miłosierdzia, tradycji, współczucia lub interpretacji, który stanowi jedną z wielu współczesnych koncepcji etyki postmetafizycznej ${ }^{36}$. Vattimo twierdzi, że w naszych czasach nie ma miejsca na obiektywne normy moralne, ponieważ byt człowieka nie posiada wewnętrznej struktury, z której można wyprowadzić trwałe i niezmienne zasady etyczne. Jedyną etyką możliwą do przyjęcia jest etyka postmetafizyczna - szukając swych własnych indywidualnych zasad postępowania, człowiek powinien jedynie interpretować zdarzenia i myśli, czyny i słowa.

Vattimo dokonuje sekularyzacji pojęcia współczucia, ujmując je nade wszystko jako zdolność słuchania przekazów przeszłości w nowej formie. Współczucie zdobywa swoje znaczenie poprzez śmiertelność, skończoność i nietrwałość. Etyka współczucia rodzi się na gruncie świadomości śmiertelności i ułomności, świadomie uznaje własną słabość wynikającą z tego, że nie ma już bezpiecznej normy, z której można wyprowadzić konkretne zachowania. Dlatego też zwraca się w stronę narracji symbolicznych, pomników, tego wszystkiego, co może pomóc w dziele interpretacji. Etyka współczucia jest przede wszystkim etyką dóbr, nie imperatywów. Stoi ona na straży dziedzictwa ludzkiej kultury i dokonuje z szacunkiem jego interpretacji ${ }^{37}$.

36 Por. A. Kobyliński, O możliwości zbudowania etyki nihilistycznej. Propozycja Gianniego Vattima, Warszawa 2014; tenże, Etyka nihilistyczna Gianniego Vattima, w: Etyka, cz. I: Koncepcje etyki, Seria: Dydaktyka filozofii, red. St. Janeczek, A. Starościc, Lublin 2016, 215-232; K. Zathurezcky, Secularism and Christianity: Caritas in the Thought of Gianni Vattimo and Pope Benedict XVI, Toronto Journal of Theology 24(2008)2, 227-238; E. Meganck, Nihilistische caritas? Secularisatie bij Gianni Vattimo, Leuven 2005.

37 Por. G. Vattimo, Al di là del soggetto. Nietzsche, Heidegger e l'ermeneutica, Roma 1991, 11-15. 
W etyce proponowanej przez Vattima kategorie dobra i zła są zastąpione przez pojęcia współczucia i przemocy - dobre jest to, co wzmacnia współczucie i z niego wyrasta, natomiast zło jest wszędzie tam, gdzie występują jakiekolwiek formy przemocy. Nowym imperatywem moralnym staje się zasada dotycząca ograniczania przemocy oraz poszerzania przestrzeni współczucia i miłosierdzia. W ramach tej etyki nie jest możliwa jakakolwiek forma etyki szczegółowej, która wskazuje oceny i normy odnoszące się do określonych gatunków czynów ludzkich. Pozostaje jedynie ogólny imperatyw, którym jest zasada miłosierdzia oraz praktyczna reguła postępowania, aby czynić to, co ogranicza przemoc i powiększa współczucie.

Warto podkreślić, że etyka proponowana przez Vattima trafnie formułuje rozwiązania w dziedzinie więzi międzyludzkich i życia społecznego: nakazuje troskę o słabych, wykluczonych, doświadczonych przez zło i przemoc. Natomiast w pewnym stopniu pozostaje bezradna wobec współczesnych problemów bioetycznych. Widać to jasno na przykładzie „bioetyki bez dogmatów”, którą proponuje Vattimo. Tego rodzaju wersja bioetyki postmetafizycznej, wolnej od kategorii natury ludzkiej czy prawa naturalnego, zbliża się do współczesnych form utylitaryzmu i akceptuje większość negatywnych przejawów współczesnej rewolucji biotechnologicznej.

\section{PODSUMOWANIE}

Bardzo złożony fenomen sekularyzacji wymaga obecnie szeroko zakrojonych badań interdyscyplinarnych. Wielką rolę do odegrania $\mathrm{w}$ tej dziedzinie ma także rzetelna analiza filozoficzna. Dzięki filozofii można lepiej rozumieć współczesne metamorfozy fenomenu religii. W ostatnich latach załamał się definitywnie paradygmat sekularyzacji - okazało się, że modernizacja oraz rozwój naukowo-techniczny nie muszą prowadzić do nieuchronnej śmierci religii. W społeczeństwach zdominowanych przez islam, buddyzm czy hinduizm zasadniczo nie ulega zmianie społeczna funkcja religii. Natomiast w świecie 
zachodnim procesy sekularyzacyjne łączą się obecnie z desekularyzacją i narodzinami społeczeństwa postsekularnego.

Symbole religijne wyzwolone $\mathrm{z}$ kontekstu instytucjonalnego coraz częściej pojawiają się w mediach, w sztuce, a nawet w polityce. W ten sposób granice tego, co religijne i niereligijne, stają się mniej określone, do pewnego stopnia płynne. Coraz częściej mówi się nie tyle o zmierzchu religii, ile o zmianie jej funkcji w życiu społecznym. Warto zauważyć, że w niektórych krajach zachodnich wzmacnia się, z jednej strony, obecność islamu, z drugiej - ulega dalszemu osłabieniu społeczne znaczenie religii chrześcijańskiej ${ }^{38}$.

Najgłębsze znaczenie sekularyzacji dotyczy dzisiaj nie tyle obecności religii w domenie publicznej, ile reinterpretacji prawd i symboli religijnych. Analiza tego wymiaru sekularyzacji stanowi obecnie wielkie wyzwanie dla takich dyscyplin filozoficznych, jak antropologia, etyka, historia idei czy filozofia religii. Bez rzetelnego namysłu filozoficznego trudno uchwycić istotę współczesnych procesów sekularyzacyjnych i desekularyzacyjnych, które prowadzą do narodzin nowej wizji religii, człowieka, moralności czy kultury.

Prekursorem sekularyzacji jako reinterpretacji prawd i symboli religijnych był Rainer Maria Rilke, który nie odrzucił w swojej twórczości tradycji chrześcijańskiej, ale poddał ją głębokiej metamorfozie. Austriacki poeta ujmował sekularyzację nie jako zanik religijności, ale jako jej metamorfozę i całkowitą prywatyzację. Zamykając fenomen religii w wymiarze czysto immanentnym, antycypował obecny kształt procesów sekularyzacyjnych i desekularyzacyjnych. Przedmiotem jego zainteresowań nie była sekularyzacja, która kształtuje rzeczywistość według zasady ,jakby Boga nie było" (etsi Deus non daretur), ale sekularyzacja jako forma nowego rozumienia prawd i symboli chrześcijańskich oraz metamorfoza fenomenu religijnego z rzeczywistości obiektywnej w różnorodne formy zindywidualizowane i immanentne.

38 Por. J. Springer, Katholikentagsroutine, Christ in der Gegenwart 68(2016)23, 247. 
Podobną wizję sekularyzacji prezentuje Gianni Vattimo, który postuluje religię w wersji słabej, subiektywnej, pozbawionej transcendencji. Włoski myśliciel twierdzi, że prawdy religijne poddane reinterpretacji $\mathrm{w}$ ramach procesu sekularyzacji mają znaczenie jedynie metaforyczne. Tego rodzaju religijność zsekularyzowana nie akceptuje jakichkolwiek dogmatów religijnych lub moralności o charakterze obiektywnym i normatywnym. Sekularyzacja jako forma nowego rozumienia prawd i symboli chrześcijańskich tworzy warunki możliwości nowego modelu etycznego - nazywanego przez Vattima etyką miłosierdzia, tradycji, współczucia lub interpretacji - który stanowi jedną z wielu współczesnych koncepcji etyki postmetafizycznej.

\section{BIBLIOGRAFIA}

Augé M., Genio del paganesimo, Bollati Boringhieri, Torino 2002.

Berger P.L., Sekularyzacja a problem wiarygodnosci religii, tłum. z ang. W. Kurdziel, w: Ateizm oraz irreligia i sekularyzacja, red. F. Adamski, Wydawnictwo Petrus, Kraków 2011, 96-112.

Berger P.L., The Desecularization of the World. A Global Overview, w: The Desecularization of the World. Resurgent Religion and World Politics, red. tenże, Grand Rapids, Washington D.C. 1999, 1-18.

Destro A., Rilke. Il Dio oscuro di un giovane poeta, Messaggero Edizioni, Padova 2003.

Fischer N., Rilkes Zugang zur Religion. Gegen die Hypothese seiner „Immanenz-Gläubigkeit", w: „Gott" in der Dichtung Rainer Maria Rilkes, red. tenże, Felix Meiner Verlag, Hamburg 2014, 69-106.

Gadamer H.-G., Kleine Schriften II, Mohr Siebeck Verlag, Tübingen 1967.

Gogarten F., Destino e speranza dell'epoca moderna. La secolarizzazione come problema teologico, Morcelliana Edizioni, Brescia 1972.

Gorski Ph. S., Historicizing the Secularization Debate: Church, State, and Society in Late Medieval and Early Modern Europe, CA. 1300 to 1700, w: Secularization, t. I, Defining Secularization. The Secular in Historical and Comparative Perspective, red. B.S. Turner, SAGE Publications, Los Angeles 2010, 117-158.

Guardini R., Rainer Maria Rilke. „Le Elegie duinesi” come interpretazione dell'esistenza, Morcelliana Edizioni, Brescia 1974.

Guardini R., Studi su Dante, Morcelliana Edizioni, Brescia 1986. 
Habermas J., Wierzyć i wiedzieć, Znak 568(2002)9, 8-21.

Harris M., Vattimo, Nibilism and Secularization: the "Trojan Horse" Effect of Christianity, Parrhesia 9(2014), 51-64.

Introvigne M., Il sacro postmoderno. Chiesa, relativismo e nuovi movimenti religiosi, Gribaudi Editore, Milano 1996.

Jahnel C., „Entwicklung“: ein säkulares Heilsversprechen? Religion und Entwicklung post-säkular denken und interpretieren, Berliner Theologische Zeitschrift 32(2015)2, 319-342.

Jesi F., Esoterismo e linguaggio mitologico. Studi su Rainer Maria Rilke, Casa Editrice Quodlibet, Macerata 2002.

King M., Pilger und Prophet: heilige Autorschaft bei Rainer Maria Rilke, Vandenhoeck \& Ruprecht, Göttingen 2009.

King M., Säkularisierung und Re-Sakralisierung: Rainer Maria Rilke als "poeta vates" der Moderne, w: Ästhetik-Religion - Säkularisierung, t. II, Die klassische Moderne, red. S. Vietta, S. Porombka, Wilhelm Fink Verlag, München 2009, 89-107.

Kobyliński A., Etyka nihilistyczna Gianniego Vattima, w: Etyka, cz. I: Koncepcje etyki, Seria: Dydaktyka filozofii, red. S. Janeczek, A. Starościc, Wydawnictwo KUL, Lublin 2016, 215-232.

Kobyliński A., O możliwości zbudowania etyki nibilistycznej. Propozycja Gianniego Vattima, Wydawnictwo UKSW, Warszawa 2014.

Kobyliński A., Sekularyzacja i doświadczenie religijne, Collectanea Theologica 76(2006)1, 123-146.

Krasnodębski Z., Spoteczeństwo postsekularne, Znak 562(2002)3, 5-12.

Laudazi E., Dio e l'uomo nelle „Elegie duinesi” di R. M. Rilke, Rivista di Vita Spirituale 62(2008)1, 53-68.

Manera E., La poetica di R. M. Rilke nella riflessione sul mito di Furio Jesi, Estetica (2009)1, 21-47.

Mariański J., Sekularyzacja, desekularyzacja. Nowa duchowość. Studium socjologiczne, Zakład Wydawniczy NOMOS, Kraków 2013.

Mariański J., Sekularyzacja i desekularyzacja w nowoczesnym świecie, Wydawnictwo KUL, Lublin 2006.

Meganck E., Nibilistische caritas? Secularisatie bij Gianni Vattimo, Peeters Publishers, Leuven 2005.

Mucci G., Il bisogno di Dio, La Civiltà Cattolica 3980(2016)8, 182-186.

Natoli S., Dio e il divino. Confronto con il cristianesimo, Morcelliana Edizioni, Brescia 1999. 
Rilke R. M., Elegie duinejskie, w: tenże, Kto mówi o zwycięstwach? Przetrwanie jest wszystkim!, tłum. z niem. B. Antochewicz, Wydawnictwo Silesia, Wrocław 1994, 149-174.

Springer J., Katholikentagsroutine, Christ in der Gegenwart 68(2016)23, 247.

Stock A., Linien des Lebens. Zu späten Gedichten Hölderlins, Stimmen der Zeit 141(2016)2, 115-120.

Vattimo G., Addio alla verità, Maltemi Editore, Roma 2009.

Vattimo G., Al di là del soggetto. Nietzsche, Heidegger e l'ermeneutica, Feltrinelli Editore, Roma 1991.

Vattimo G., Credere di credere. È possibile essere cristiani nonostante la Chiesa?, Garzanti Editore, Milano 1996, $1999^{2}$.

Vattimo G., Dopo la cristianità. Per un cristianesimo non religioso, Garzanti Editore, Milano 2002.

Vattimo G., Girard R., Verità o fede debole? Dialogo su cristianesimo e relativismo, Transeuropa Edizioni, Massa 2006.

Wacker G., Poetik des Prophetischen. Zum visionären Kunstverständnis in der Klassischen Moderne, Walter De Gruyter Verlag, Berlin - Boston 2013.

Wawrzynek K., Rainer Maria Rilke and his Mystical Russia, Studia Europaea Gnesnensia 7(2013), 263-284.

Weber M., Wissenschaft als Beruf, w: tenże, Schriften 1894-1922. Ausgewählt und herausgegeben von Dirk Kaesler, Alfred Kröner Verlag, Stuttgart 2002, 474-511.

Zathurezcky K., Secularism and Christianity: Caritas in the Thought of Gianni Vattimo and Pope Benedict XVI, Toronto Journal of Theology 24(2008)2, 227-238.

\section{SECULARIZATION OF RELIGION IN THE WRITINGS OF RAINER MARIA RILKE AND GIANNI VATTIMO}

\footnotetext{
Abstract. The main aim of this article is to analyze the phenomenon of secularization in the writings of Rainer Maria Rilke and Gianni Vattimo and to offer a profound reinterpretation of the ethics of charity, as built on the foundations of religion. In recent years there has been a breakdown of the secularization paradigm. It turned out that modernity and contemporary technological revolution do not necessarily lead to the inevitable death of religion. Many contemporary scientists tell us about the process of desecularization and the return of religion in a modified form. The deepest meaning of secularization does not concern the presence of religion in the public domain, but the reinterpretation of religious truths and symbols. In this regard the main problem is to establish a new form of religion, entirely immanent and humanistic. These very complex phenomena of secularization and desecularization require extensive interdisciplinary research.
} 
Keywords: secularization, desecularization, post-secular society, death, nihilism, hermeneutics, post-metaphysical ethics

\section{ANDRZEJ KOBYLIŃSKI}

a.kobylinski@uksw.edu.pl

Uniwersytet Kardynała Stefana Wyszyńskiego w Warszawie, Instytut Filozofii Wóycickiego 1/3, 01-938 Warszawa

DOI: $10.21697 /$ spch.2016.52.3.02 